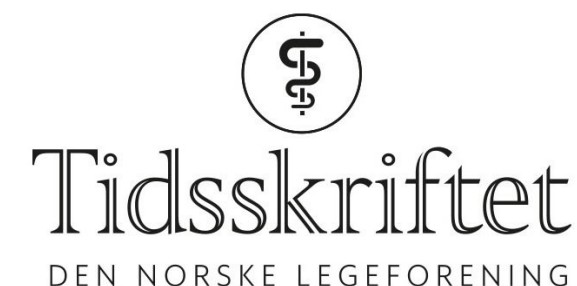

\title{
Rettelse: Kreftutvikling og befolkningssammensetning i Norge 1990-2016
}

RETTELSE

KIRSTI VIK HJERKIND

INGER KRISTIN LARSEN

BJØRN MØLLER

GISKE URSIN

Tidsskr Nor Legeforen 2018; 138: 1824-9.

I Tidsskriftet nr. 19/2018 på s. 1826 skal figurteksten til Figur 1 være: Endring i forekomsten av alle kreftformer hos norskfødte (stiplet linje) og totalbefolkningen (rett linje) vist som aldersstandardiserte insidensrater (norsk standard) i perioden 1990-2016.

Vi beklager feilen, den er rettet på nett.

Publisert: 28. november 2018. Tidsskr Nor Legeforen. DOI: 10.4045/tidsskr.18.og16 (C) Tidsskrift for Den norske legeforening 2020. Lastet ned fra tidsskriftet.no 